European Journal of Adapted Physical Activity, 1(1), 35-49

(C) European Federation of Adapted Physical Activity, 2008

\title{
PHYSICAL SELF-PERCEPTIONS AND SELF-ESTEEM IN MALE BASKETBALL PLAYERS WITH AND WITHOUT DISABILITY: A PRELIMINARY ANALYSIS USING THE PHYSICAL SELF-PERCEPTION PROFILE
}

\author{
José Pedro Ferreira \\ Centro de Estudos Biocinéticos, Laboratório de Psicologia do Desporto e do Exercício, Faculdade \\ de Ciências do Desporto e Educação Física, Universidade de Coimbra
}

Kenneth R. Fox

Department of Exercise and Health Sciences, University of Bristol

The purposes of this study were threefold. The first aim was to test the reliability and validity of a Portuguese version of the Physical Self-Perception Profile (PSPPp) in elite basketball players and determine its sensitivity to assess Self-perceptions in athletes with and without physical disabilities. The second aim was to assess the relationship between variables such as length of sport career, frequency of doing sport and competitive level, and Self-perceptions in the physical domain as well as Global Self-esteem both in athletes with and without disability. The third aim was to assess the relationship between disability-specific variables such as lesion source, type of lesion, time onset of disability and functional classification, and Self-perceptions in the physical domain as well as Global Self-esteem in athletes with disability. The psychometric properties and validity of the PSPPp were evaluated with a sample basketball players with $(n=64)$ and without disability $(n=69)$. Cronbach alpha values for subscales ranged from .66 to .79 for the disability group and from.62 to .73 for the group without disability. Exploratory factor analysis revealed a different factorial organization to that reported with the original instrument. The hierarchical organisation of the PSPPp subscales was partially supported by correlation and partial correlation analyses especially in basketball players without disability.

KEYWORDS: Physical Self-perception Profile, Physical Self, Self-esteem, Disability Sport.

\section{INTRODUCTION}

Self-esteem has been widely accepted as an important indicator of emotional stability, adjustment to life demands and therefore mental health. The Physical Self has also emerged as consistently important, demonstrating moderately strong correlations with Global Self-esteem (GSE) throughout the lifespan (Fox, 2000). Understanding Selfdevelopment processes has increased in importance as Self-esteem and Self-perception components have become increasingly valued in educational, clinical and community health programmes (USDHHS, 1999).

The multidimensional organization of the Physical Self (Fox \& Corbin, 1989), revealed the Physical Self-Worth (PSW), i.e., the global summary of all the perceptions in the physical domain, acting as a mediator between Physical
Self-perceptions and the Global Self-esteem, carrying important emotional adjustment qualities (Sonstroem \& Potts, 1996).

Furthermore, the assessment of Physical Self-perceptions has becoming more sophisticated in the past 15 years reflecting multidimensionality and hierarchical organisation (Marsh, 1997) as well as the development of instruments in line with theoretical frameworks (Fox, 1998) such as the Physical Self Perception Profile - PSPP (Fox \& Corbin, 1989) and the Physical Self Description Questionnaire - PSDQ (Marsh, Richards, Johnson, Roche, \& Tremayne, 1994). However, this new generation of instrumentation has rarely been applied to populations with disability in most of the European countries.

PSPP is one of the most world widely used instruments to measure the Physical Self. Its 
psychometric properties have been established through several published studies with a range of populations, in cultures other than the original US population used in its development. These include English (Page, Ashford, Fox, \& Biddle, 1993), Spanish (Atienza, Balaguer, \& Moreno, 1997), Russian (Hagger, Ashford, \& Stambulova, 1998), Turkish (Asci, Asci, \& Zorba, 1999), Flemish (Van de Vliet, Knapen, Onghena, Fox, Van Coppenolle, David, Pieters, \& Peuskens, 2002) and Portuguese populations (Fonseca \& Fox, 2002; Ferreira \& Fox, 2007). PSPP has also been used with other age groups than university or college students, such as children and youth (Welk, Corbin, \& Lewis, 1995; Whitehead, 1995; Eklund, Whitehead, \& Welk, 1997; Hagger, Ashford, \& Stambulova, 1998; Crocker, Eklund, \& Kowalsky, 2000) and adults in their middle or later years (Sonstroem, Speliotis, \& Fava, 1992; Van der Vliet et al., 2002) with good results.

The development of Self-perceptions in groups with disabilities has become a central issue in the last decades, in particular since the social model of disability (Oliver, 1996; Sherrill, 1993) revealed disability as a multidimensional identity that is specific to culture and history, is socially constructed, and is mediated by time of onset, nature of the impairment, socioeconomic status, gender, ethnicity, and the multitude of roles, expectancies, aspirations, and perceptions that each individual incorporates into the Self.

As disability is viewed as a form of social oppression involving social imposition of restrictions of activity on people with impairments and the socially engendered undermining of their psycho-emotional wellbeing (Thomas, 1999), people with disabilities are a risk group for mental health disorders like depression, anxiety, stress, frustration, lack of motivation, social withdrawal, mostly as a consequence of social phenomena such as discrimination, prejudice and stigma as major forms of social segregation.

The physical world of sport and exercise is seen as a particularly revealing arena for examining critical relationship between disability and the Self (Sherrill, 1997). Sherrill,
Hinson, Gench, Kennedy and Low (1990) made an early attempt to assess the Selfconcept of disability youth athletes using a standardized instrument, the Self-Concept Inventory (Harter, 1988). In spite of the gender and age limitations found and few previous data for comparison it was suggested that youth disability athletes presented a general patterns of Self-concept similar to those of youth athletes without disability. These patterns were more similar to those found in adult athletes with disability when compared with their peers without disability. Other studies revealed that international athletes with disability present higher levels of Self-esteem than national, regional and recreational athletes (Campbell \& Jones, 1994).

Previous studies using other instruments with weaker psychometric properties, reported a significant association between the level of participation in sport and Global Self-esteem (Szyman, 1980). Furthermore, Patrick (1986) reported a significant increase in the Selfesteem scores of novice wheelchair athletes after a period of five months of involvement in sport competition, when compared with those presented by wheelchair veterans with three or more years of experience. These results confirmed those reported by Green, Pratt and Grigsby (1984) suggesting that Self-esteem increases during the first years followed by a period of stability four years after the occurrence of the lesion. In all studies, those who presented lower initial levels of Selfesteem gained the greatest improvements.

Blinde and McClung (1997) examined the impact of recreational activities on perceptions of the physical and social Self of twenty-three individuals with physical impairment using research interview to explore their experiences of participation. Results revealed several ways in which participation in individualized recreational programs enhanced perceptions of both physical and social Self. These included experiencing the body in new ways, enhanced perceptions of physical attributes, redefined physical capabilities and increasing perceived confidence to pursue new physical activities.

However, sport and exercise involvement effects are not so linear enhancing perceptions 
about the Self and the Body across the review of literature. Smith and Sparkes (2002) analysed the self-memories of 14 men who experienced spinal cord injury (SCI) through their involvement in playing rugby football union and who lived the experience of entering formal SCI rehabilitation. The participants were encouraged to tell their life stories in their own way and using their own words.

Findings revealed that participants used different types of narrative to report their own life stories. For those living with a chaos narrative, with an absence of order and a lack of plot (Frank, 1995), sport participation does not bring about improvements in coping with disability (Sparkes, 1998; Sparkes \& Smith, 2002). Participants using a restitution narrative revealed an affinity for the restored Self and the entrenched Self (Charmaz, 1987) that locks the individual into their past Self-Body relationships and ways of being in the world with the hope that they will return to their original state (Smith, 2004). For these men the concrete hope is "yesterday I was able-bodied, today I am disabled, but tomorrow I'll be ablebodied again" (Smith \& Sparkes, 2005). This type of narrative emphasises positive responses and outcomes and it is a story of coping with illness (or disability), rebuilding the Body Self, and remoralisation (Kleinman \& Seeman, 2000).

Finally, those participants using a quest narrative truly believe that something is to be gained from the disability experience (Frank, 1995). Quest stories were about being transformed, developing the Self, and the teller given something by the experience of disability that is then passed on to others in the telling (Smith, 2004).

In contrast to the restitution narratives that incorporate concrete hope, quest stories foster and embrace transcendent hope (Smith \& Sparkes, 2005) as a type of hope that is not oriented to achieving a fixed and specific outcome, but instead embraces uncertainty and finitude, celebrating surprise, play, novelty, mystery and openness to change (Marcel, 1962). For this particular group, sport may impede rather then facilitate re-embodiment and so sport as a form of rehabilitation to promote enjoyment, a valued sense of Self, and competence may not be useful for all men with SCI acquired through playing sport (Smith, 2004).

In spite of all these studies, the contribution of Physical Self and Self-esteem for personal empowerment and identity in groups with disability is still not totally clear and the positive or negative role of sport in this process requires further extensive research.

The main purpose of the present study was to test validity and reliability of a Portuguese version of the PSPP with elite basketball athletes with and without disability. The second aim of this study was to analyse the relationships between variables such as length of sport career, frequency of doing sport and competitive level and Self-perceptions in the physical domain as well as Global Self-esteem in basketball athletes with and without disability. A third aim was to assess the relationships between specific disability variables such as lesion source, type of lesion, time onset of disability and sport classification, and Self-perceptions in the physical domains as well as the Global Self-esteem in basketball athletes with disability.

\section{METHODS}

Study design

Two sets of data from Portuguese elite basketball players with and without disability were used in this study to facilitate comparison between groups.

\section{Participants}

The study involves a sample of 137 basketball players participating in the National Basketball Competition. Sample A subjects were 64 wheelchair basketball players, 5 females and 59 males from eight teams playing in the National Wheelchair Competition. The five female wheelchair basketball players were kept as part of the male sample due to the fact that no female wheelchair basketball competition exists in Portugal, and these female athletes play the game integrated in male teams experiencing similar opportunities and personal empower-ment. The mean age for basketball players with physical disability was $32.81 \pm 11.36$ years. This sample represents 
$85 \%$ of all wheechair basketball players competing in Portugal. Sample B subjects were 69 male athletes without disability from eight different teams competing at different levels of the National Competition (professional league, $1^{\text {st }}$ division and $2^{\text {nd }}$ division). The mean age for athletes without disability was $20.91 \pm 4.55$ years.

\section{Measures}

Participants received a test battery containing a Portuguese version of the Physical Self-Perception Profile - PSPPp (Fonseca, Fox $\&$ Almeida, 1995) and a Portuguese version of the Rosenberg Self-esteem Scale - RSESp (Abrantes, 1991).The Physical Self-Perception Profile - PSPP (Fox \& Corbin, 1989) consists of five sub-scales with six items displayed in a structured alternative format with a possible range of scores from 6 to 24. Subjects are presented with two contrasting descriptions of people and they are asked to select the description most like themselves and afterwards the intensity of the agreement with that description, i.e., to choose whether this description is "sort of true to me" or "really true to me". This structured alternative format was developed by Harter (1985) and has been shown to overcome socially desirable responding (Fox, 1990). The psychometric properties of the PSPP were presented by Fox (1990) and have been replicated since then in many published studies. In Fox's original studies, internal consistency coefficients ranged from .81 to .92 and test-retest coefficients ranged from $\mathrm{r}=.74$ to .92 over a 16-day period and between $r=.81$ and .88 over a 23 day period. For the Portuguese population Ferreira and Fox (2007) reported test-retest reliability correlation coefficients ranged from $r=.66$ to .88 for female and from $r=.58$ to. 84 for male, for a 16-day lapse period.

The Rosenberg Self-esteem Scale - RSES (Rosenberg, 1965) is a uni-dimensional tenitem instrument using a four-point Likert Scale to which participants respond from strongly agree to strongly disagree. Global Self-esteem is represented by the sum of all item scores providing a possible range of 10 to 40 with higher scores indicating higher Self-esteem (GSE). RSES has been validated in many different studies (Hagborg, 1993) as well as in the Portuguese population. Silber and Tippett (1965) reported a test-retest reliability value of .85. Batista (1995) using this instrument with Portuguese adolescents (11-17 yrs.) reported a test-retest reliability coefficient of $r=.74$ and Ferreira and Fox (2007) using a broader sample of 1052 student (16-30 yrs.) reported a testretest reliability coefficient of $r=.75$.

\section{Procedures}

Participants were tested in small groups ranging from 5 to 12 individuals after training sessions, with previous consent from coaches and from the National Organisation. The test battery was administrated by the same research assistant after a short briefing about the purpose of the study. Standardized instructions were given to all participants as well as encouragement to ask for help. Individual attention was given to athletes with interpretation doubts, questions were read to clarify the meaning assuring that no emphasis was put on the question in order to avoid directing the answer.

\section{Statistical analysis}

The full range of descriptive statistics was calculated for all domains and sub-domains. An alpha level of .05 was used for all statistical tests. In spite of the small sample size validation of the PSPPp was undertaken using exploratory factor analyses (EFA). Principal components analysis with robust rotation is calculated for each sample (A and B) in order to establish the independence and integrity of the PSPPp subscales in Portuguese basketball players with and without disability. Four factors were extracted to confirm the original structure of the PSPP proposed by Fox and Corbin (1989). The Physical Self-Worth subscale is not entered as it has been established as a superordinate construct representing combined outcome of the remaining subscales. The final factorial structure is selected based on the same criteria previously used for validation of the PSPPp for the Portuguese population (Ferreira \& Fox, 2007). Internal consistency of the different scales is assessed using Cronbach's alpha coefficients (Cronbach, 1951). Bivariate and partial correlations, including zero-order 
correlation coefficients, were used to analyse the relationship between the different PSPPp sub-domains as well as with Global Selfesteem. Stepwise multiple regression was used to assess the level of explained variance in the PSW by the remaining PSPPp sub-scale scores.

Comparisons between samples are done using non-parametric statistics (Kruskal-Wallis Test for $\mathrm{k}$ independent samples and MannWhitney Test for two independent samples) motivated by the small sample size in some subgroups in variables such as: length of sport career, frequency of doing sport, competitive level, time onset of disability, type of lesion, lesion source and functional classification.

\section{RESULTS}

Table 1 provides a comparison of sub-scale mean score values and standard deviations from groups with and without disability as well as from other samples of Portuguese students used in previous studies with the same instrument (Ferreira \& Fox, 2007).

Table 1

Means and standard deviations from PSPP subscales - basketball players with and without disability

\begin{tabular}{|l|c|c|c|c|c|c|c|c|}
\hline \multirow{4}{*}{ Subscales } & \multicolumn{2}{|c|}{$\begin{array}{c}\text { Wheelchair } \\
\text { basketball }\end{array}$} & \multicolumn{2}{c|}{$\begin{array}{c}\text { Basketball } \\
\text { players }\end{array}$} & $\begin{array}{c}\text { Sport Sciences } \\
\text { university } \\
\text { students } \\
\text { sample C }\end{array}$ & $\begin{array}{c}\text { Secondary school } \\
\text { students } \\
\text { sample D }\end{array}$ \\
\cline { 2 - 9 } & \multicolumn{2}{|c|}{$\mathrm{N}=64$} & \multicolumn{2}{c|}{$\mathrm{N}=69$} & \multicolumn{2}{c|}{$\mathrm{n}=143$} & \multicolumn{2}{c|}{$\mathrm{n}=225$} \\
\cline { 2 - 9 } sample B & $\mathrm{M}$ & $\mathrm{SD}$ & $\mathrm{M}$ & $\mathrm{SD}$ & $\mathrm{M}$ & $\mathrm{SD}$ & $\mathrm{M}$ & $\mathrm{SD}$ \\
\hline SPORT & 16.61 & 3.20 & 17.32 & 2.80 & 17.09 & 3.05 & 16.36 & 3.33 \\
\hline CONDITION & 16.44 & 3.18 & 17.32 & 2.85 & 17.64 & 3.42 & 16.12 & 3.49 \\
\hline PHYCONF & 17.02 & 3.99 & 18.07 & 2.86 & - & - & 16.65 & 3.53 \\
\hline BODY & 14.92 & 3.43 & 16.07 & 3.10 & 16.60 & 3.45 & 15.50 & 3.25 \\
\hline STRENGTH & 16.53 & 3.14 & 15.94 & 3.02 & 15.79 & 3.32 & 15.28 & 3.09 \\
\hline PSW & 16.50 & 3.61 & 16.93 & 2.80 & 17.66 & 3.59 & 16.26 & 3.41 \\
\hline GSE & 23.56 & 3.39 & 30.19 & 4.28 & 31.66 & 4.94 & 30.88 & 4.55 \\
\hline
\end{tabular}

The mean score values from sample $\mathrm{C}$ students are from second, third and fourth year university male students $(n=143)$ attending a Sport and Physical Education degree course (mean age was $21.80 \pm 3.39$ years). The mean score values from sample D students are from male Portuguese secondary school students $(\mathrm{n}=225)$ from the $10^{\text {th }}$ and $11^{\text {th }}$ grades (mean age $17.43 \pm .64$ years) from eight secondary schools in the Centre of Portugal. All the students in sample D were sedentary, i.e., were not doing any sport and physical activity other than the usual physical education classes at school.

Sport Science and Physical Education university students showed the highest levels of perceived Physical Self when compared with all the other sub-groups. Inactive secondary school students showed the lowest level of perceived Physical Self. Basketball players without disability showed higher levels of perceived Physical Self than basketball players with disability but lower levels of perceived Physical Self than Sport Science and Physical Education university students. Basketball players with physical disability showed higher levels of perceived Physical Self than inactive secondary students without disability in all PSPPp domains except for Body Attractiveness where they reported the lowest perceived score of all the sub-groups in the study. In opposition, basketball players with disability 
reported the highest score for perceived Physical Strength than any other sub-group in the study.

With regard to Global Self-esteem, results revealed that Portuguese students reported higher levels of GSE than elite basketball athletes. Sport Sciences students reported the highest mean score values while basketball athletes with disability reported the lowest mean score values for GSE from all the subgroups in the study.

Exploratory factor analysis results from athletes with disability revealed four initial factors that explained $50.70 \%$ of the total variance among the subscale items (see Table 2). EFA for the basketball athletes without disability also revealed four initial factors that explained $46.85 \%$ of the total variance (see Table 3).

Table 2

Principal components factor loadings for PSPP items - wheelchair basketball players $(n=64)$

\begin{tabular}{|c|c|c|c|c|c|}
\hline Sub-scale & Item $\mathrm{N}^{\circ}$ & $\begin{array}{c}\mathrm{F} 1 \\
\text { loadings }\end{array}$ & $\begin{array}{c}\mathrm{F} 2 \\
\text { loadings }\end{array}$ & $\begin{array}{c}\mathrm{F} 3 \\
\text { loadings }\end{array}$ & $\begin{array}{c}\mathrm{F} 4 \\
\text { loadings }\end{array}$ \\
\hline $\begin{array}{c}\text { PHYSICAL } \\
\text { CONFIDENCE } \\
\text { (SPORT + } \\
\text { CONDITION) }\end{array}$ & $\begin{array}{c}\mathbf{2} \\
\mathbf{1 2} \\
\mathbf{1 7} \\
\mathbf{1 1} \\
19 \\
\mathbf{2 1} \\
23 \\
29\end{array}$ & $\begin{array}{l}.60 \\
.84 \\
.67 \\
.80 \\
.75 \\
.58 \\
.49 \\
.57\end{array}$ & & & \\
\hline BODY & $\begin{array}{c}3 \\
\mathbf{1 8} \\
\mathbf{2 8} \\
9 \\
14 \\
\end{array}$ & & $\begin{array}{l}.62 \\
.63 \\
.49 \\
.64 \\
.78 \\
\end{array}$ & & \\
\hline F3 & $\begin{array}{c}4 \\
6 \\
7 \\
24 \\
27\end{array}$ & & & $\begin{array}{l}.49 \\
.61 \\
.75 \\
.49 \\
.60\end{array}$ & \\
\hline F4 & 22 & & & & .71 \\
\hline Eigenvalue & & 4.12 & 3.05 & 2.93 & 2.07 \\
\hline$\%$ Variance & & 17.15 & 12.71 & 12.22 & 8.62 \\
\hline Cum. \% Variance & & 17.15 & 29.86 & 42.08 & 50.70 \\
\hline
\end{tabular}


Table 3

Principal components factor loadings for PSPP items - basketball players without disability $(\mathrm{n}=69)$

\begin{tabular}{|c|c|c|c|c|c|}
\hline Sub-scale & Item $\mathrm{N}^{\circ}$ & $\begin{array}{c}\mathrm{F} 1 \\
\text { loadings }\end{array}$ & $\begin{array}{c}\mathrm{F} 2 \\
\text { loadings }\end{array}$ & $\begin{array}{c}\mathrm{F} 3 \\
\text { loadings }\end{array}$ & $\begin{array}{c}\mathrm{F} 4 \\
\text { loadings }\end{array}$ \\
\hline F1 & $\begin{array}{c}2 \\
11 \\
12 \\
13 \\
21 \\
23 \\
28\end{array}$ & $\begin{array}{l}.49 \\
.61 \\
.73 \\
.63 \\
.72 \\
.66 \\
.45\end{array}$ & & & [.43] \\
\hline STRENGTH & $\begin{array}{c}1 \\
4 \\
9 \\
19 \\
24 \\
29\end{array}$ & [.40] & $\begin{array}{l}.63 \\
.62 \\
.76 \\
.56 \\
.70 \\
.58\end{array}$ & & \\
\hline $\begin{array}{c}\text { PHYSICAL } \\
\text { CONFIDENCE } \\
\text { (SPORT + } \\
\text { CONDITION) }\end{array}$ & $\begin{array}{c}\mathbf{6} \\
14 \\
\mathbf{1 6} \\
\mathbf{2 2} \\
\mathbf{2 6} \\
\mathbf{2 7}\end{array}$ & & & $\begin{array}{l}.47 \\
.54 \\
.75 \\
.65 \\
.57 \\
.55\end{array}$ & \\
\hline BODY & \begin{tabular}{c|}
$\mathbf{3}$ \\
$\mathbf{8}$ \\
17 \\
$\mathbf{1 8}$
\end{tabular} & & & & $\begin{array}{l}.61 \\
.48 \\
.53 \\
.76 \\
\end{array}$ \\
\hline Eigenvalue & & 3.51 & 2.97 & 2.59 & 2.18 \\
\hline$\%$ Variance & & 14.62 & 12.36 & 10.78 & 9.09 \\
\hline Cum. \% Variance & & 14.62 & 26.97 & 37.76 & 46.85 \\
\hline
\end{tabular}

Note: For clarity only loadings for the expected factors and unexpected loadings (cross loadings in brackets) exceeding .40 are included.

Results of EFA with data from athletes without disability support the hierarchical model previously suggested by Fonseca and Fox (2002) and Ferreira and Fox $(2002,2007)$ for the Portuguese population as indicated in Table 3. There is a clear definition of three factors - Physical Confidence, Body and Strength - as subscales for the Physical Self. In the specific case of wheelchair basketball players EFA results partially support this model, with only two factors - Physical Confidence and Body - being clearly defined as indicated in Table 2. A significant number of cross loadings are found for Strength subscale in this particular group with disability.

Subscale reliability showed an acceptable internal consistency with coefficient Cronbach alphas values of .79 and .66 for Physical Confidence and Body in the group with disability and alpha values of $.65, .62$ and .73 for Physical Confidence, Body and Strength subscales in the group without disability. Testretest reliability correlation coefficients ranged from $r=.72$ to .88 for females and from $r=.73$ to .83 for males, for a 16-day lapse period. RSES also presented a test-retest reliability value of $r=.72$ with a 14-days period between applications.

The subscale interrelationships for the Portuguese model are analysed using correlation and partial correlation coefficients, providing partial evidence for the proposed hierarchical organization with Global Selfesteem (Table 4). 
Table 4

Correlation and partial correlation coefficients controlling PSW effects - wheelchair basketball players (sample A)

\begin{tabular}{|l|l|l|l|l|}
\hline & GSE & PSW & PHYCONF & BODY \\
\hline PSW & .18 & & & \\
\hline PHYCONF & $\begin{array}{l}.04 \\
(-.05)\end{array}$ & $.45^{*}$ & & \\
\hline BODY & $\begin{array}{l}-.03 \\
(-.15)\end{array}$ & $52^{*}$ & $\begin{array}{l}.20 \\
(-.05)\end{array}$ & \\
\hline STREN & $\begin{array}{l}.07 \\
(-.03)\end{array}$ & $.48^{*}$ & $\begin{array}{l}.28^{* *} \\
(.09)\end{array}$ & $\begin{array}{l}.40^{*} \\
(.20)\end{array}$ \\
\hline
\end{tabular}

Partial correlation coefficients controlling PSW effects presented in brackets

* Coefficients significant at $.01 \quad * *$ Coefficients significant at .05

GSE correlated more highly with PSW than all the other subscales at the base of the hierarchy. Each of the sub-domain scales showed a stronger relationship with PSW than with GSE as was predicted. This relationship supports the existence of the PSW construct as a generalized outcome of perceptions in the four sub-domains and as a mediator between these sub-domains and GSE. Although weaker relationship between the three sub-domain scales were seen when controlling the PSW effects, partial correlation coefficients also showed that the relationship between GSE and the three sub-domain scales increased when the effects of PSW were statistically removed. This is in contrast to previous work indicating that in groups without disability, PSW functions as a mediating variable between the three subdomains and GSE.

Multiple regression analysis (stepwise method) revealed that the three sub-domain scales were able to explain only $44.4 \%$ of the variance in PSW for wheelchair basketball athlete's and $46.0 \%$ for basketball athlete's without disability in contrast to $55-70 \%$ in studies with other populations (Fox \& Corbin, 1989; Page et al., 1993; Van de Vliet et al., 2002). Ferreira and Fox (2007) reported a value of $68.6 \%$ of the variance explained for the Portuguese Youth male population.

With regard to Physical Confidence, Mann-Whitney Test results for two independent samples showed significant statistical differences between national and international athletes with disability
$(\mathrm{U}=235.0, \quad p \leq .01)$. International athletes presented higher mean score values than national athletes. Regarding Physical SelfWorth, Kruskal-Wallis Test results for $\mathrm{k}$ independent samples showed marginal values in athletes with disability doing sport 1 or 2 times per week and athletes with disability doing sport 3 or 4 times per week $\left(\chi^{2}\right.$ $(1)=3.354, p=.067)$. Significant statistical differences are also found for physical strength, in athletes without disability doing sport 3 or 4 times per week and those doing sport 5 or more times per week $\left(\chi^{2}(1)=4.491, p \leq .05\right)$. Athletes doing sport more times per week perceived lower levels of perceived Physical Strength.

Finally and regarding Global Self-esteem Kruskal-Wallis Test results showed significant statistical differences among athletes without disability with different lengths of sport career $\left(\chi^{2}(2)=7.613, p \leq .05\right)$. Mann-Whitney Test results revealed that those differences existed between athletes without disability and with until 4 years of sport career and athletes without disability and with 11 or more years of sport career $(\mathrm{U}=46.0, p \leq .05)$, and between athletes without disability with 5 to 10 years of sport career and athletes without disability with 11 or more years of sport career $(\mathrm{U}=241.5$, $p \leq .05)$. Athletes with longer sport careers reported higher levels of Self-esteem. Furthermore, differences in Global Self-esteem are also found in athletes with disability experiencing different frequencies of doing sport $\left(\chi^{2}(2)=4.272, p \leq .05\right)$. Mann-Whitney 
test results showed differences between athletes with disability doing sport 1 or 2 times per week and those doing sport 3 or 4 times per week $(\mathrm{U}=264.5 ; \mathrm{p} \leq .05)$. Athletes doing sport more times per week reported higher values of Self-esteem.

Comparison between groups for disability specific variables such as lesion source, type of lesion, time onset of disability and sport classification with Physical Self and Global Self-esteem revealed significant statistical differences for Body Attractiveness in athletes with disability from different sport classification classes $\left(\chi^{2}(7)=14.618, p \leq .05\right)$ with athletes from lower sport classes (lower functional abilities) expressing lower levels of satisfaction with their body.

\section{DISCUSSION}

A major caution when discussing results from the present study is due to the small sample size. In spite of this limitation EFA was used to understand the behaviour of the different variables and compare the solution found with previous studies with the Portuguese population. On the other hand hypothesised sample size effects may be reduced as sample A participants $(n=64)$ represent $85 \%$ of all individuals playing wheelchair basketball in Portugal.

The purpose of this study was to investigate reliability and validity of the Portuguese version of the Physical SelfPerception Profile, the PSPPp, with male Portuguese basketball athletes with or without physical disability. Support was provided for the three factors model previously suggested by Fonseca and Fox (2002), and Ferreira and Fox (2003, 2007) for the Portuguese population. Results from EFA with male basketball athletes without disability confirmed the existence of Physical Confidence, Body and Strength as subscales of the Physical Self, explaining all together $46.85 \%$ of the variance in Physical Self-Worth. Cronbach Alpha values were .70 or above revealing an acceptable internal consistency for each subscale.

But the situation was less clear with wheelchair basketball players. Although the major portion of content used to express general feelings of Physical Self-worth appeared to arise from the three sub-domains used in the PSPPp, only limited support was found for the discriminant validity of the three sub-domain subscales. They failed to form distinct factors in the factor analyses. This suggests that the content of these subscales may possess different meanings and connotations to wheelchair athletes and that there is overlap in the content between subscales.

Furthermore, PSW as an indicator of Physical Self-worth did not clearly operate as a mediator between the three sub-domains and Global Self-esteem. This is an unusual finding not seen previously in studies using the PSPP with a wide range of populations. Expected relationships among constructs existed but were weaker and the three sub-domains explained a much smaller percentage of Physical Self-Worth than in groups without disability. Although, these athletes with disability scored high in Sport, Condition, Body and Strength, this contributed less than might be expected to Physical Self-Worth but much less for Global Self-esteem.

These unusual results suggest that the Physical Self in athletes with physical disabilities has different characteristics or structure than the general population, however, results from the present study imply that either Physical Self-perceptions content is different or is utilised differently when formulating Selfidentity and determining Self-esteem. The pattern found for Physical Self and Global Self-esteem in this group may be understood as a particular characteristic or may be determined by the difference provided by dealing and living with physical disability in a competitive sport environment.

Comparison between the two samples supported the hypothesis that basketball athletes without disability have higher mean score values on the PSPPp subscales as well as for GSE than wheelchair basketball athletes with physical disability revealing higher levels of emotional stability and adjustment to life. Comparison between basketball athletes and other sedentary individuals suggest that basketball athletes have higher mean score 
values on the PSPPp as well as on the GSE than sedentary individuals. The main exception was found in male wheelchair athletes (samples A) that unexpectedly showed the highest mean score value for Physical Strength, reinforcing the subjective as well as the objective importance of Physical Strength in individual's with physical disabilities daily lives (Ferreira, 2006) and the lowest mean score value for Body when compared with male groups without disability.

Considering the importance attributed to appearance and image in today's society, physical disability may have an important impact on the way people with physical disability perceive their bodies. This may result from frequent segregational social attitudes and stigma towards disabled bodies supporting the idea suggested by Taleporos and McCabe (2002) that physical disability can adversely impact feeling of physical and sexual attractiveness as well as strong negative feelings towards the body. Individuals with physical disability, in particular during late adolescence and early adulthood, may be more sensitive and critical about their physical appearance, especially during a period when their colleagues without disability value the shape and the size of their bodies in such a positive way.

With regard to Self-esteem results showed that athletes doing sport more times per week and athletes with a longer sport career presented higher levels of GSE, both in athletes with and without physical disability. These results may support the positive effects of exercise and sport participation in people with physical disabilities, enhancing perceptions of physical attributes, redefining physical capabilities and increasing perceived confidence in new physical activities (Blinde \& McClung, 1997) but may also explain why people with disability reporting higher levels of self-perception are attracted to and persevering in sport. Furthermore, wheelchair sport athletes showed lower mean score values for GSE when compared with their basketball colleagues without disability (sample B) as well as with other sedentary groups without disability. These athletes showed high mean score values for all PSPPp sub-domains but they seem not to be seen as having an important influence over Global Self-esteem. In spite of considering the physical part of their bodies as something relevant for their daily lives, wheelchair basketball athletes may consider that this physical part does not play a determining role in influencing approval or disapproval attitudes towards them as a whole person. These results do not support those traditionally described in the disability sport literature suggesting strong relationships between sport participation and Global Selfesteem in wheelchair athletes as well as that general improvements in Self-esteem result from sport participation (Hopper, 1986; Szyman, 1980; Valliant, Bezzubyk, Daley, \& Asu, 1985).

However, these results fully support the idea that taking part in sport and exercise is moderately associated with more positive Physical Self-perceptions from late adolescence onwards (Fox \& Corbin, 1989; Sonstroem, Speliotis, \& Fava, 1992) and that sport and exercise participation are weakly associated with Global Self-esteem and that this relationship is inconsistent and probably dependent on population, environmental, and individual characteristics (Fox, 2000). Group characteristics may help to understand these findings.

\section{CONCLUSIONS}

A general view of the results would initially suggest that the Portuguese version of the PSPP has showed limited validity for the assessment of Portuguese wheelchair sport athlete's self-perceptions in the Physical domain. Only two of the three sub-dimensions, Physical Confidence and Body, were clearly defined among Portuguese wheelchair sport athletes. The factor structure is less clear than with non-disabled groups. However the differences seen in relationships among the constructs between groups with and without disability has provided some insight into the sources of differences in content recorded. It has also provided some indication that Global Self-esteem is influenced in different ways in wheelchair athletes to athletes without 
disability whose Physical Selves seems to be structured similar to general populations.

However, in these particular disability sport settings, individual's Self-perceptions may be developing in an alternative way, due to the specificity of the group as well as to environmental and socialization conditions in which the sport occurs (Ferreira \& Meek, 2001). Individual Self-perceptions in groups with physical disability may be perceived in a different way, focusing different aspects of the Body and different approaches to the Physical Self rather than those traditionally identified in groups without disability.

Wheelchair sport athletes develop perceptions about their bodies through strong feelings about their ability to perform in competitive sport contexts - achievement through sport - providing a unique opportunity to perform successfully complex sport skills and tasks as well as to reveal a personal ability to perform in high stressful environments, assessing the limits of their "bodies with disability". The sport arena is an important context where people with physical impairment find opportunities to experience new challenges, to test their capacities, to create confidence and formulate stronger views of their bodies, as well as to experience exposure to social assessment.

Athletes with physical disability doing sport presented clear feelings of Physical Confidence (Sport Competence and Physical Condition) and Body Attractiveness as a result of a more positive opinion about the physical ability of their bodies in disability sport. However, these positive feeling do not extent to Self-esteem because in this particular group Physical Self-Worth does not work as a mediator, as usually reported in the review of literature for all other groups without disability. In spite of considering the Physical Self as something relevant to their lives, this group of wheelchair basketball athletes might consider that the Physical Self does not play an important role modelling their attitudes and believes towards their own feelings of personal competence and the way their see themselves as active social elements. Segregational social attitudes towards their Body might lead to a permanent memory about their physical limitations playing great influence on the way people manage with their physical disability or causing anxiety related to the Body (Taleporos $\&$ McCabe, 2001).

The results from the present study also suggest that further research is needed to provide richer insight into how self-perceptions in groups with physical disability develop in a different way to athletes without disability. Complementary qualitative study could provide an important contribution by corroboration of quantitative findings with questionnaires and also new richer information about details of content in sub domains, the factors that influence Self-perceptions and how the Physical Self is related to Self-esteem.

\section{REFERENCES}

Abrantes, P. (1991). Reacções emocionais a doença grave: Como lidar. Coimbra: Almedina.

Asci, F. H., Asci, A., \& Zorba, E. (1999). Cross-cultural validity and reliability of the Physical Self-Perception Profile. International Journal of Sport Psychology, 30, 399406.

Atienza, F., Balaguer, I., \& Moreno, Y. (1997). Factorial validity of the Physical SelfPerception Profile (PSPP) in the case of Spanish adolescents. In R. Lidor \& M. BarEli (Eds.), Innovations in Sport Psychology: Linking theory and practice - Proceedings of the IX World Congress of Sport Psychology (pp.82-84). Israel.

Batista, P. (1995). Satisfação com a imagem corporal e autoestima - estudo comparativo de adolescentes envolvidas em diferentes níveis de actividade física. Tese de Mestrado em Ciências do Desporto. Universidade do Porto. Not published.

Blinde, E., \& McClung, L. R. (1997). Enhancing the physical and social self through recreational activity: Accounts of individuals with physical disabilities. Adapted Physical Activity Quarterly, 14, 327-344.

Campbell, E., \& Jones, G. (1994). Psychological well-being in wheelchair sport 
participants and nonparticipants. Adapted Physical Activity Quarterly, 11, 404-415.

Charmaz, K. (1987). Struggling for a self: Identity levels of the chronically ill. In P. Conrad \& J. Roth (Eds.), The sociology of health care: A research manual, Vol. 6 (pp. 283-321). Greenwich, Connecticut: JAI Press Inc.

Crocker, P. R. E., Eklund, R. C., \& Kowalsky, K. C. (2000). Children's physical activity and physical self-perceptions. Journal of Sport Sciences, 18, 383-394.

Cronbach, L. J. (1951). Coefficient alpha and the internal structure of tests. Psycho-metrika, 16, 297-334.

Eklund, E. C., Whitehead, J. R., \& Welk, G. J. (1997). Validity of the children and youth Physical Self-Perception Profile: A confirmatory factor analysis. Research Quarterly for Exercise and Sport, 68, 249-256.

Ferreira, J. P. (2006). Physical Self and Global Self-esteem in Wheelchair Sport Participants: A mixed method approach. Coimbra: FCDEF-UC, Centro de Estudos Biocinéticos.

Ferreira, J. P., \& Fox, K. R. (2007). An investigation into the structure, reliability, and validity of the Physical Self-Perception Profile in non-English spoken settings. International Journal of Applied Sport Sciences, 19(1), 25-46.

Ferreira, J. P., \& Fox, K. R. (2003). Evidence of cross-cultural validity and reliability of a Portuguese version of the Physical SelfPerception Profile. In R. Stelter (Ed.) Collection of articles of the XIth European Congress of Sport Psychology - FEPSAC (CD-Rom). Copenhagen.

Ferreira, J. P., \& Fox, K. R. (2002). Crosscultural validity of a Portuguese version of Physical Self-Perception Profile. In M. Koskolou, N. Geladas, \& V. Klissouras (Eds.), Proceedings of the 7th Annual Congress of the European College of Sport Sciences, Vol. 1 (p. 531). Athens.

Ferreira, J. P., \& Meek, G. A. (2001). Portuguese wheelchair athletes selfperceptions in the physical domain: Preliminary analysis. Proceedings of the 13th International Symposium, 5th European
Congress of Adapted Physical Activity (p. 50). Vienna.

Fonseca, A., \& Fox, K. R. (2002). Como avaliar o modo como as pessoas se percebem fisicamente? Um olhar sobre a versão portuguesa do Physical Self-Perception Profile (PSPP). Revista Portuguesa de Ciências do Desporto, 2, 11-23.

Fonseca, A., Fox, K. R., \& Almeida M. J. (1995). Portuguese version of Physical SelfPerception Profile (PSPP-P). Not published.

Fox, K. R. (2000). The effects of exercise on Self-perceptions and Self-esteem. In S. J. H. Biddle, K. R. Fox, \& S. H. Boutcher (Eds.), Physical Activity and Psychological WellBeing (pp. 88-117). London: Routledge.

Fox, K. R. (1998). Advances in the Measurement of the Physical Self. In J. L. Duda (Ed.), Advances in Sport and Exercise Psychology Measurement. Morgantown: Fitness Information Technology, Inc.

Fox, K. R. (1990). The Physical SelfPerception Profile Manual. DeKalb, IL: Office for Health Promotion, Northern Illinois.

Fox, K. R., \& Corbin, C. B. (1989). The Physical Self-Perception Profile: Development and preliminary validation. Journal of Exercise and Sport Psychology, 11, 408-430.

Frank, A. W. (1995). The wounded storyteller. Body, illness and ethics. Chicago: Chicago University Press.

Green, B. C., Pratt, C. C., \& Grigsby, T. E. (1984). Self-concept among persons with long-term spinal cord injury. Archives of Physical Medicine and Rehabilitation, 65, 751-754.

Guthrie, S. R. (1999). Managing imperfection in a perfectionistic culture: Physical activity and disability management among women with disabilities. Quest, 51, 369-381.

Hagborg, W. J. (1993). The Rosenberg Selfesteem Scale and Harter's Self-Perception Profile for Adolescents: A concurrent validity study. Psychology in the Schools, 30, 132136.

Hagger, M., Ashford, B., \& Stambulova, N. (1998). Russian and British children's physical self-perceptions and physical 
activity participation. Pediatric Exercise Science, 10, 137-152.

Harter, S. (1985). The Self-Perception Profile for Children. Unpublished manual.

Harter, S. (1988). Manual for the Selfperception Profile for Adolescents. Denver: CO: Author.

Hopper, C. (1986). Socialization of wheelchair athletes. In C. Sherrill (Ed.), Sport and disabled athletes (pp. 197-202). Champaign, IL: Human Kinetics.

Kleinman, A., \& Seeman, D. (2000). Personal experiences of illness. In G. Albrecht, R. Fitzpatrick, \& S. Scrimshaw (Eds.), Handbook of Social Studies in Health and Medicine (pp. 230-242). London: Sage.

Marcel, G. (1962). Homo Viator. New York: Harper and Row.

Marsh, H. W. (1997). The measurement of Physical Self-concept: A construct validation approach. In K. R. Fox (Ed.), The Physical Self: From motivation to well-being. Leeds: Human Kinetics.

Marsh, H. W., Richards, G., Johnson, S., Roche, L., \& Tremayne, P. (1994). Physical Self Description Questionnaire: Psychometric properties and a multitrait-multimethod analysis of relations to existing instruments. Journal of Sport and Exercise Psychology, 16, 270-305.

Oliver, M. (1996). Understanding Disability: From Theory to Practice. London: Macmillan Press Ltd.

Page, A., Ashford, B., Fox, K., \& Biddle, S. (1993). Evidence of cross-cultural validity for the Physical Self-Perception Profile. Personality and Individual Differences, 14, 585-590.

Patrick, G. D. (1986). The effects of wheelchair competition and acceptance of disability in novice athletes. Therapeutic Recreation Journal, 20, 61-71.

Rosenberg, M. (1965). Society and the adolescent self-image. Princeton, $\mathrm{NJ}$ : Princeton University Press.

Sherrill, C. (1997). Disability, Identity and Involvement in Sport and Exercise. In K. R. Fox (Ed.) The Physical Self: From Motivation to Well-Being (pp. 257-286). Champaign, IL: Human Kinetics.
Sherrill, C. (1993). Adapted Physical Activity, Recreation and Sport: Crossdisciplinary and Life Span. Champaign, IL: Human Kinetics.

Sherrill, C., Hinson, M., Gench, B., Kennedy, S. O., \& Low, L. (1990). Self-concepts of disabled youth athletes. Perceptual and Motor Skills, 70, 1093-1098.

Silber, E. \& Tippett, J. S. (1965). Self-esteem: Clinical assessment and measurement validation. Psychological Reports, 16, 10171071.

Smith, B. (2004). The potential of narrative: The example of becoming disabled throughsport. In J. P. Ferreira, P. M. Gaspar, C. F. Ribeiro, A. M. Teixeira, \& C. Senra (Ed.), Physical Activity and promotion of Mental Health (pp. 23-28). Coimbra: Faculdade de Ciências do Desporto e Educação Física, Universidade de Coimbra.

Smith, B., \& Sparkes, A. C. (2002). Men, sport, spinal cord injury and the construction of coherence: narrative practice in action. Qualitative Research, 2, 143-171.

Smith, B., \& Sparkes, A. C. (2005). Men, sport, spinal cord injury, and narratives of hope. Social Science and Medicine, 61, 1095-1105.

Sonstroem, R. J., Speliotis, E. D., \& Fava, J. L.(1992). Perceived physical competence in adults: An examination of the Physical SelfPerception Profile. Journal of Sport and Exercise Psychology, 14, 207-221.

Sonstroem R. J., \& Potts, S. A. (1996). Life adjustment correlates of Physical Selfconcepts. Medicine and Science in Sport and Exercise, 28, 619-625.

Sparkes, A. C. (1998). Athletic identity: An Achilles' heel to the survival of self. Qualitative Health Research, 8, 644-664.

Sparkes, A. C., \& Smith, B. (2002). Sport, spinal cord injury, embodied masculinities, and the dilemmas of narrative identity. Men and Masculinities, 4, 258-285.

Szyman, R. J. (1980). The effect of participation in wheelchair sports. University of Illinois, Urbana-Champaign.

Taleporos, G., \& McCabe, M. P. (2001). The impact of physical disability on body esteem. Sexuality and Disability, 19, 293-308. 
Taleporos, G., \& McCabe, M. P. (2002). Body image and physical disability: Personal Perspectives. Social Science and Medicine, 54, 971-980.

Thomas, C. (1999). Female Forms: Experiencing and Understanding Disability. Buckingham: Open University Press.

USDHHS (1999). Mental health: A report of the Surgeon General - Executive Summary. Rockville, MD: US Department of Health and Human Services, Substance, Abuse and Mental Health Services Administration, Centre for Mental Health Services, National Institute of Mental Health.

Valliant, P. M., Bezzubyk, I., Daley, L., \& Asu, M. E. (1985). Psychological impact of sport on disabled athletes. Psychological Reports, 56, 923-929.

Van de Vliet, P., Knapen, J., Onghena, P., Fox, K. R., Van Coppenolle, H., David, A.,
Pieters, G., \& Peuskens, J. (2002). Assessment of physical self-perceptions in normal Flemish adults versus depressed psychiatric patients. Personality and Individual Differences, 32, 855-863.

Welk, G. J., Corbin, C. B., \& Lewis, L. A. (1995). Physical self-perceptions of high schoolathletes. Pediatric Exercise Science, 7, 152-161.

Whitehead, J. R. (1995). A study of children's physical self-perceptions using an adapted Physical Self-Perception Profile Questionnaire. Pediatric Exercise Science, 7, 132151.

Corresponding author's e-mail address: jpferreira@fcdef.uc.pt

\section{PHYSISCHE SELBSTWAHRNEHMUNG UND SELBSTWERTGEFÜHL BEI MÄNNLICHEN BASKETBALLSPIELERN MIT UND OHNE BEHINDERUNG: EINE VORLÄUFIGE ANALYSE MIT HILFE DES PHYSICAL SELF-PERCEPTION PROFILE}

(Resümee)

Diese Studie verfolgte drei Ziele. Das erste Ziel war die Überprüfung von Reliabiliät und Validität einer portugiesischen Version des Physical Self-Perception Profile (PSPPp) zur Erfassung des physischen Selbstkonzeptes bei Elite-Basketballspielern sowie dessen Sensitivität zur Einschätzung des Selbstkonzepts von Athleten mit und ohne körperlichen Behinderungen festzulegen. Das zweite Ziel war die Erfassung der Beziehungen zwischen Einflussgrößen wie Dauer der sportlichen Karriere, Häufigkeit der Sportausübung sowie Wettkampflevel und der Selbstwahrnehmung in der physischen Dimension sowie des generellen Selbstwerts von Athleten mit und ohne Behinderung. Das dritte Ziel der Studie war es, die Relation zwischen behinderungsspezifischen Variablen, wie Verletzung-sursache, Art der Verletzung, Zeitpunkt des Beginns von Behinderung und funktionaler Klassifizie-rung, und der Selbstwahrnehmung im physischen Bereich sowie dem generellen Selbstwertgefühl von Athleten mit Behinderungen zu beurteilen. Die psychometrischen Eigenschaften und die Validität des PSPPp wurden mit einer Stichprobe von Basketballern mit $(n=64)$ und solchen ohne Behinderung $(n=69)$ evaluiert. Die Cronbach-Alpha-Werte für die Subskalen nahmen Werte von 0.66 bis 0.79 für die Gruppe der Spieler mit Behinderung und Werte zwischen 0.62 und 0.73 für die Gruppe ohne Behinderung an. Eine erste Faktorenanalyse ergab eine unterschiedliche faktoriale Anordnung im Vergleich zum ursprünglichen Instrumentarium. Die hierarchische Organisation der PSPPp Subskalen wurde teilweise bestätigt durch Korrelations- und partieller Korrelationsanalysen speziell bei den Spielern ohne Behinderung.

SCHLÜSSELWÖRTER: Physical Self-Perception Profile, physisches Selbst, Selbstwertgefühl, Behindertensport. 


\section{PERCEPTION PHYSIQUE ET ESTIME DE SOI CHEZ LES JOUEURS DE BASKET- BALL EN SITUATION DE HANDICAP OU NON : UNE ANALYSE PRELIMINAIRE UTILISANT LE PROFIL DE PERCEPTION PHYSIQUE DE SOI (PHYSICAL SELF-PERCEPTION PROFILE)}

(Résumé)

Les objectifs de cette étude étaient triples. Le premier but était de tester la fiabilité et la validité d'une version portugaise du Profil de Perception Physique de Soi (Physical Self-Perception Profile (PSPPp)) chez l'élite des joueurs de basket-ball et de déterminer sa sensibilité pour évaluer la perception que les sportifs valides et non valides ont d'eux-mêmes. Le second but était d'évaluer la relation entre des variables comme la longueur d'une carrière sportive, la fréquence de la pratique sportive, le niveau de compétition et la perception de soi dans les domaines physiques ainsi que d'une manière générale chez les sportifs valides et non valides. Le troisième but était d'évaluer la relation entre des variables spécifique au handicap comme la source de la lésion, le type de lésion, le temps écoulé depuis l'accident, la classification fonctionnelle et la perception de soi dans les domaines physiques ainsi que d'une manière générale chez les sportifs valides et non valides. Les propriétés psychométriques et la validité du PSPPp ont été évaluées sur un échantillon de basketteurs non valides $(n=64)$ et valides $(n=69)$. Les valeurs de l'alpha de Cronbach pour les sous-échelles vont de .66 à .79 pour le groupe non valide et de .62 à .73 pour le groupe valide. L'analyse factorielle exploratoire révèle une organisation factorielle différente de ce qui avait été reporté avec l'instrument initial. L'organisation hiérarchique des sous échelles PSPPp a été partiellement confortée par des analyses de corrélations et de corrélations partielles notamment chez les joueurs valides.

MOTS CLEFS: Profil de perception physique de soi, Estime de soi, Handicap, Sport. 